\title{
Application of Rhododendron for Human Welfare: A Review
}

Priyanka Rawat, Anju Rani', Mansi Chauhan, Anushka Khanna, Nandini Pathak, Raj Singh ${ }^{2}$, Chhaya Singh ${ }^{3}$, Neha Chauhan ${ }^{4}$

10.18805/ag.R-2146

\begin{abstract}
National flower of Nepal and Uttarakhand is Rhododendron arboreum locally called buransh, a small tree with bright red flowers and green leaves. Rhododendron is derived from a Greek word RHODO and DENDRON which means rose-tree is used traditionally as medicine and also as food. Buransh normally grows in Himalayas, at high altitude is being used popularly for its processed juice from flowers as buransh or sharbat and in medicines that has many health benefits. Burans products are also used in decorations, refreshing drinks, firewood and as food colouring agents. Its numerous use also include in treatment of bile's and liver disorders, nasal bleeding, blood dysentery, stomach ache, asthma, fever, gout, coughs, blurry vision, heart problems and diabetes. This review focuses on the phytochemical and nutrition profile, pharmacological and biological properties of Rhododendron arboreum in sustainable development of rural population with many job opportunities.
\end{abstract}

Key words: Biological activities, Buransh, Medicinal, Phytochemical and nutrition profile.

Rhododendron arboretum has extremely variable flower color, hardness, stature and characteristic leaf. Rhododendron and arboreum are Greek word which means rose tree and tree like appearance respectively (Orwa et al., 2009). Rhododendron was originally detected in North Central India is now seen in the Himalayas from Jand $\mathrm{K}$ to Bhutan and in the hills of Manipur and Assam at an altitudes of $1200-4000 \mathrm{~m}$. It is an evergreen with very large branching reach upto $14 \mathrm{~m}$ height and $2.4 \mathrm{~m}$ girth (Chauhan et al., 1999) and grows up to 40 to 50 feet height sometimes upto 100 feet (Rai and Rai, 1994). In Garhwal, this tree has both ecological and economic significance and usually found in higher altitudes, above $1500 \mathrm{~m}$. Out of 72 species, 20 subspecies and 19 varieties were listed from India (Mao et al., 2001). The hot spot for Rhododendron diversity with 75 species, 4 subspecies and five varieties is The Eastern Himalayan region while Western Himalaya has only 6 species (Sastry and Hajra et al., 2010). The fully blossomed artistic beauty of the flowers attracts the attention across the country (Srivastava, 2012) and has been declared as the National flower of Nepal and State flower of Himachal Pradesh. Rhododendron possess health benefits in preventing and treatment of diarrhea, heart, detoxification, asthma inflammation, constipation, dysentery, bronchitis and fever (Nisar et al., 2013). Leaves have adequate antioxidant action with young leaves used to alleviate headache. The wood is used to make gun- stocks, kukri handles, gift boxes, pack saddles and posts (Saklani and Chandra, 2015). Other botanical description clearly showed in the Table 1.

\section{Phytochemical and nutriitional profile}

Rhododendron contains $\mathrm{Mn}, \mathrm{Fe}, \mathrm{Zn}, \mathrm{Cu}, \mathrm{Na}, \mathrm{Cr}, \mathrm{Co}, \mathrm{Cd}$, $\mathrm{Mo}, \mathrm{Ni}, \mathrm{Pb}$ and arsenic that play a vital role to maintain some physicochemical processes that are very essential for life. Sodium $(\mathrm{Na})$ is important to maintain the osmotic balance
Department of Life Sciences and Biotechnology, Graphic Era deemed to be University, Dehradun-248 002, Uttarakhand, India. ${ }^{1}$ Department of Botany, Keral Verma Subharti College of Science, Swami Vivekanand Subharti University, Meerut-250 001, Uttar Pradesh, India.

2Department of Biotechnology, Maharishi Markandeshwar (Deemed to be University), Mullana, Ambala-133 207, Haryana, India.

${ }^{3}$ Department of Botany, Government Degree College, Thalisain246 285, Uttarakhand, India.

${ }^{4}$ Department of Microbiology, College of Paramedical Sciences, Shri Guru Ram Rai University, Dehradun-248 001, India.

Corresponding Author: Anju Rani, Department of Botany, Keral Verma Subharti College of Science, Swami Vivekanand Subharti University, Meerut-250 001, Uttar Pradesh, India.

Email: anjurani.ar1@gmail.com

How to cite this article: Rawat, P., Rani, A., Chauhan, M., Khanna, A., Pathak, N., Singh, R., Singh, C. and Chauhan, N. (2021). Application of Rhododendron for Human Welfare: A Review. Agricultural Reviews. DOI: 10.18805/ag.R-2146.

Submitted: $11-12-2020$ Accepted: 30-07-2021 Online: 03-08-2021

between cells and interstitial fluid (Soetan et al.,2010). Rhododendron contains good amount of secondary metabolites like tannins, steroids, alkaloids, flavonoids, saponins, glycosides and phlobatannins (Nisar et al., 2013). Various phtyochemicals have been recognised and isolated from the different parts of R.arboreum that have protective or disease preventive properties. They include - flavonoids, alkaloids, saponins, tannins, phytosterols, reducing sugars and phenolic compounds. Isolated flavonoids include Quercetin-3-O-galactoside and Quercetin from flower and leaves while sterols include beta-sistosterol from leaves. Flavonol glycoside rutin isolated from leaves and quercitrin from flower whereas triterpenoid 3-O-acetylbetulinic acid, betulin and lupeol generated from bark. Many phytochemicals 
from different parts have also been isolated from which are as under:

\section{Bark}

Petroleum ether extract of the bark contained a triterpenoid substances 3-0-acetylbetulinic acid $\left(\mathrm{C}_{32} \mathrm{H}_{50} \mathrm{O}_{4}\right)$, beta sitosterol-3-O-beta - D glucosidose $\left(\mathrm{C}_{32} \mathrm{H}_{50} \mathrm{O}_{4}\right)$, 3-betaacetoxyurs-11-en-13-beta,28-olide $\left(\mathrm{C}_{32} \mathrm{H}_{48} \mathrm{O}_{4}\right)$; botulin $\left(\mathrm{C}_{30} \mathrm{H}_{50} \mathrm{O}_{2}\right)$;lupeol $\left(\mathrm{C}_{30} \mathrm{H}_{50} \mathrm{O}\right) ; 3-\mathrm{O}$ acetylursolic acid $\left(\mathrm{C}_{32} \mathrm{H}_{50} \mathrm{O}_{4}\right)$; taraxerol $\left(\mathrm{C}_{30} \mathrm{H}_{50} \mathrm{O}\right)$; ursolic acid $\left(\mathrm{C}_{30} \mathrm{H}_{48} \mathrm{O}_{3}\right)$;15oxoursolic acid $\left(\mathrm{C}_{30} \mathrm{H}_{46} \mathrm{O}_{4}\right)$. The ether extract of the bark following petroleum ether extract showed the identity of betulinic acid $\left(\mathrm{C}_{30} \mathrm{H}_{48} \mathrm{O}_{3}\right)$ while acetone extract gave leucopelargonidin $\left(\mathrm{C}_{15} \mathrm{H}_{14} \mathrm{O}_{6}\right)$ (Hariharan and Rangaswami, 1966).

\section{Flowers}

Quercetin -3-O-glactoside $\left(\mathrm{C}_{21} \mathrm{H}_{20} \mathrm{O}_{12}\right)$ is a flavonoid compound extracted from $R$.arboreum. Three active phenolic compounds et al, quercetin $\left(\mathrm{C}_{15} \mathrm{H}_{10} \mathrm{O}_{7}\right)$, rutin $\left(\mathrm{C}_{27} \mathrm{H}_{30} \mathrm{O}_{16}\right)$ and coumaric acid $\left(\mathrm{C}_{9} \mathrm{H}_{8} \mathrm{O}_{3}\right)$ have been reported in flowers of $R$. arboreum using high-performance thin-layer chromatography
(HPTLC). There are many other compounds that isolated in methanolic flower extract (Swaroop, 2005).

\section{Leaves}

The green leaves of the plant contain flavonoids Quercetin -3-O-glactoside $\left(\mathrm{C}_{21} \mathrm{H}_{20} \mathrm{O}_{12}\right)$ and quercetin $\left(\mathrm{C}_{15} \mathrm{H}_{10} \mathrm{O}_{7}\right)$. It contains sterol beta-sitosterol $\left(\mathrm{C}_{29} \mathrm{H}_{50} \mathrm{O}\right)$, a new triterpenoid named campanulin, quercetin and hyperoside $\left(\mathrm{C}_{21} \mathrm{H}_{20} \mathrm{O}_{12}\right)$. Chemical analysis of arboreum indicated the presence of pentacyclictriterpenoid compounds which include alphaamyrin, beta-amyrin, friedelin $\left(\mathrm{C}_{30} \mathrm{H}_{50} \mathrm{O}\right)$. Leaves are also reported to contain the flavone glycoside rutin $\left(\mathrm{C}_{27} \mathrm{H}_{30} \mathrm{O}_{16}\right)$ and dimethyl ester of terephthalic acid (Painuli et al., 2015; Jegan and Selvaraj, 2016). Jegan and Selvaraj (2016) reported about 34 compounds out of it some are major compounds detected in Gas chromatography and mass spectrometry analysis of methanolic extract of leaves. Compounds detected were beta-amyrin, heptadecane, 22stigmasten- 3-one, tetradecane, methyl ester, linoleic, linoleyl alcohol, beta-citronellol, dodecane, L-ascorbic acid, 2, 6- dihexadecanoate, alpha-amyrin and dibutyl phthalate.

Table 1: Botanical description of the plant.

\begin{tabular}{ll}
\hline Part of the plant & Description \\
\hline Trunk & Trunk is often much branched, crooked or gnarled (Orwa et al., 2009). Bark is reddish brown, soft and rough \\
& exfoliating in thin flakes (Chauhan et al., 1999). \\
& Leaves oblong-lanceolate, 10-20 cm long, crowded and narrowed towards the ends of branches, glabrous \\
Leaves & above, white or rusty brown-tomentose beneath petiole covered with white scales when young (Orwa et al., \\
& 2009). It is glossy green, with deeply impressed veins from above white fawn, cinnamon or rusty brown felt \\
is found at the under surface (Rai and Rai 1994).
\end{tabular}

Flowers

Calyx and Corolla

Stamens and Ovary

Fruit and Seeds

Growing season and Type

Classification
Flowers many in terminal, large, globose, compact corymbs and varies in color from a deep scarlet to red with white markings, deep red or pink to white in colour. Bearing about 20 blossoms in a single branch (Orwa et al., 2009).

Calyx small with broadly ovate, scarious pale yellow lobes. Corolla campanulate, $2.5-6.5 \mathrm{~cm}$ long with 5 recurved, fringed lobes and tube is spotted funnel shaped (Paxton, 1843).

Hypozygnous declining, filaments are filiform, anthers; ovate and Ovary 6 - 10-celled, style-capitate (Paxton 1834).

Fruits capsular, cylindrical, curved, longitudinally ribbed and seeds ellipsoid, minute, dark brown (Orwa et al., 2009).

In Uttarakhand normally Buransh is available in dark red colour. In the months of March - November, flowering \& fruiting occurs; prefers moist but well-drained, leafy, humus-rich acid soil. Dappled shade is the ideal sunlight requirement (Srivastava 2012).

$\begin{array}{lll}\text { Kingdom } & : & \text { Plantae } \\ \text { Phylum } & : & \text { Magnolliophyta } \\ \text { Class } & : & \text { Angiospermae } \\ \text { Order } & : & \text { Ericales } \\ \text { Family } & : & \text { Ericaceae } \\ \text { Genus } & : & \text { Rhododendron } \\ \text { Species } & : & \text { arboreum (Srivastava, 2012). } \\ \text { Garhwali } & : & \text { Burans } \\ \text { Kumaoni } & : & \text { Eras } \\ \text { Punjabi } & : & \text { Adrawal } \\ \text { Tamil } & : & \text { Billi } \\ \text { Nepali } & : & \text { Laligurans } \\ \text { Malayalam } & : & \text { Kattupoovarasu (Srivastava, 2012). }\end{array}$


(Gautam et al., 2018). In ethanolic leaf extract, about 13 compounds were identified out of these five compounds which included geraniolformate, 1-hexadecene, 1, 2, 3, propanetriyl ester, 1-octadecanol and docosanoic acid. Gautam et al., (2018) reported 26, 24 and 17 compounds in chloroform, ethyl acetate and hexane fractions respectively. The phenolic compounds, quercitrin, syringic acid, epicatechin and quercetin-3-O-galactoside in the methanolic leaves were extracted by RP-HPTLC and gallic acid in the leaves, three triterpenoids (ursolic acid, $\beta$ sitosterol and lupeol) in the flowers and leaves confirmed by HPTLC (Shilajan and Swar, 2013).

\section{Traditional uses}

Many wooden products like packsaddles, handles and giftboxes are made from the wood of $R$. arboreum and wood is used as fuel (Chettri and Sharma, 2009; Rana et al., 2015). Paste of the bark is helpful to heal the cuts (Bhattacharyya, 2011). The beautiful flowers which attract everyone, is normally used in houses decorations. Due to its sweet-sour taste, flowers are eaten raw or made into chutneys or juice. Juice is used as a freshener and is beneficial to cure fever, diabetes, rheumatism, headache and stomachache while dried flower powder is used as a drug to cure the bloody dysentery (Semwal, 2010; Sharma and Samant, 2014; Krishna, 2014; Sharma, 2010; Shilajan and Swar, 2013). Table 2 shows traditional use of different parts of $R$. arboreum.

\section{Pharmacological and biological properties Adaptogenic activity}

Medicinal value of plants has assumed importance during past few decades with diverse group of secondary metabolites with antioxidant potential which serve as plant defence mechanism against predation by insects, herbivores and microorganisms. Som et al., (2019) reported that diterpenes, triterpenes, flavonoids, steroids, tannin, phenolics, saponin, glycosides, alkaloids, tannin, quercetin and gallic acid etc. isolated from Rhododendron $\mathrm{sp}$. has potent anti-stress activity and strong anti-oxidant activity due to which it might be responsible for adaptogenic activity.

\section{Antidiarrheal activity}

The ethyl acetate fraction of Rhododendron arboretum flowers showed potent antidiarrheal activity. The fraction significantly inhibited the number of diarrheal faeces in the castor oil induced diarrhoea (Verma et al., 2010).

\section{Anti-inflammatory and anti-nociceptive activity}

The ethyl extract fraction of flower showed significant antinflammatory and anti-nociceptive effects. Gautam et al., (2018) found that ethyl acetate extract of bark of the tree showed anti-inflammatory activity against rat paw oedema. The anti-inflammatory or nociceptive effect of the extract may be due to the presence of flavonoids, tannins, saponins and other phytochemicals present either as single or in combination. The significant level of anti-inflammatory activity of the ethyl acetate extract could be attributed to high amounts of flavonoids present in the extract.

\section{Anti-oxidant and anti-mutagenic activity}

In this era of urbanization and environmental pollution, antioxidants and anti-mutagens derived from plants are the best safeguards for health of humans. Hexane, chloroform and ethyl acetate fractions of $R$. arboreum leaf extract, decreased the production of nitric oxide radicals and inhibited the lipid peroxidation. These activities might be due to the synergistic effect of phytochemicals reported in the GC-MS profiling and the presence of phytochemicals while vitamin $\mathrm{E}$ might be responsible for the antioxidant activity (Prakash et al., 2007).

Acharya et al. (2011) found that the methanolic leaf extract was moderate in antioxidant effect as compared to standard quercetin, while another study revealed that the ethanolic flower extract was high in antioxidant effect and nitric oxide synthase activation (Bhandari and Rajbhandari, 2014). Sonar et al. (2012) isolated quercetin from flower petals and estimated total flavonoid phenolic and antioxidant activity of various parts of Rhododendron arboretum.

\section{Anti-cancer activity}

Ethanolic leaf extract exhibited dose-dependent, significant activity against Agrobacterium tumefaciens induced tumour

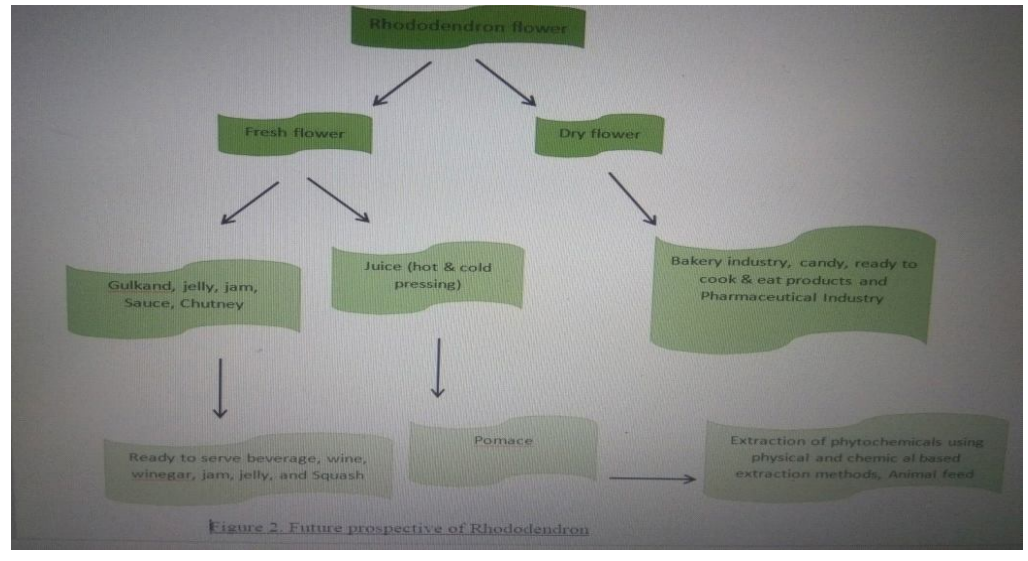

Fig 1: Future prospective of Rhododendron. 
Table 2: Traditional uses of $R$. arboretum.

\begin{tabular}{|c|c|c|}
\hline $\begin{array}{l}\text { Part of the } \\
R \text {. arboretum }\end{array}$ & Uses & Area \\
\hline \multirow[t]{2}{*}{ Bark } & Leaves and bark: reduce roughness of the skin. & $\begin{array}{l}\text { Manoor valley, Pakistan } \\
\text { (Rahman et al., 2018). }\end{array}$ \\
\hline & Bark juice: cure coughs, piles and liver disorders. & Allai valley, Pakistan (Haq, 2012) \\
\hline \multirow[t]{2}{*}{ Stem Wood } & Wood: make handles, packsaddles, gift-boxes, Gunstocks and posts. & $\begin{array}{l}\text { Arunachal Pradesh, India } \\
\text { (Paul et al., 2005). }\end{array}$ \\
\hline & Fuel & $\begin{array}{l}\text { Arunachal Pradesh, India } \\
\text { (Zhasaet al., 2015). }\end{array}$ \\
\hline \multirow{5}{*}{$\begin{array}{l}\text { Root } \\
\text { Leaves }\end{array}$} & Decoction of the roots is used in curing early stage of the cancer. & Nagaland, India (Khare, 1980). \\
\hline & $\begin{array}{l}\text { Young leaves: applied on the forehead to reduce headache } \\
\text { (Verma et al., 2010). }\end{array}$ & \\
\hline & External parasites & $\begin{array}{l}\text { Uttaranchal, India } \\
\text { (Middelkoop and Labadie, 1983). }\end{array}$ \\
\hline & Dried leaf tincture: treatment of rheumatism and gout. & $\begin{array}{l}\text { Homoeopathic material Medica } \\
\text { (Joshi et al., 2018). }\end{array}$ \\
\hline & $\begin{array}{l}\text { Asoka aristha an Ayurvedic preparation has estrogenic, oxytocic and } \\
\text { prostaglandin synthetase-inhibition effect (Acharya et al., 2011). }\end{array}$ & \\
\hline \multirow[t]{8}{*}{ Flowers } & Flower buds: vegetable. & $\begin{array}{l}\text { Uttarakhand, India } \\
\text { (Devi et al., 2018). }\end{array}$ \\
\hline & Flower aqueous extract: food colouring agent. & $\begin{array}{l}\text { Himachal Pradesh, India } \\
\text { (Dangwal et al., 2014). }\end{array}$ \\
\hline & Flowers are eaten raw, sauce and jams are also made. & $\begin{array}{l}\text { Jammu and Kashmir, India } \\
\text { (Shanmugam et al., 2011). }\end{array}$ \\
\hline & Dried flowers fried in ghee: stop the blood dysentery. & $\begin{array}{l}\text { Tamil Nadu, India } \\
\text { (Uniyal et al., 2006). }\end{array}$ \\
\hline & Crushed flowers: stop the nasal bleeding. & $\begin{array}{l}\text { Himachal Pradesh, India } \\
\text { (Kumari et al., 2015). }\end{array}$ \\
\hline & $\begin{array}{l}\text { Flower and leaves are fitted with long ropes made of munja grass } \\
\text { and tied around the houses and temples for decoration and women }\end{array}$ & \\
\hline & also decorate their hair with flowers. It has curing effect for menstrual disorders & $\begin{array}{l}\text { Himachal Pradesh, India } \\
\text { (Negi et al., 2013). }\end{array}$ \\
\hline & $\begin{array}{l}\text { Flowers juice: commercially sold as a health tonic, cure diabetes, fever, } \\
\text { stomach ache and heart-related problems and helps when fish bones } \\
\text { stuck in the throat. }\end{array}$ & $\begin{array}{l}\text { Uttarakhand, India Uttarkashi, } \\
\text { western Himalaya, India } \\
\text { Sikkim, India } \\
\text { (Nand and Naithani, 2018; } \\
\text { Tiwari and Chauhan 2006; } \\
\text { Roy 2014). }\end{array}$ \\
\hline
\end{tabular}

in potato disc. Isolated compound rutin and quercetin may be responsible for antitumor activity (Bhandary and Kuwabata et al., 2008).

\section{Anti-diabetic activity}

Anti-diabetic activity was examined in Rhododendron arboreum flower and active compounds isolated from it. According to Parcha et al., (2017), ethyl acetate soluble part was more effective in $\alpha$-glucosidase inhibitory activity than the water-soluble part.

\section{Cardioprotective activity}

Distinctive secondary metabolites of $R$. arboreum showed the potential to defuse hazardous and harmful molecules.
Ethanolic extract of $R$. arboreum whole plant, significantly decreased the activity of alanine transaminase(ALT), aspartate transaminase (AST), lactate dehydrogenase (LDH) enzymes and decreased the levels of Mass drug administration (MDA) in serum, heart tissue and increased the activity of Superoxide dismutases (SOD), catalase, glutathione peroxidase (GPx) and glutathione (GSH) in isoproterenol-treated rats. Murty et al. (2010) showed ethanolic flower extract was more effective than aqueous extract, which significantly decreased the release of lactate dehydrogenase and creatine kinase in albino rats, while the $\mathrm{n}$-butanol fraction of ethanolic extract showed maximum cardio protective activity among all the extracts. 


\section{Hypolipidemic effect}

Oral administration of Hyppophae ramnoides fruit juice + Rhododendron arboreum flower juice in 1:4 significantly reduced total cholesterol, triglycerides, low-density lipoprotein and antherogenic index (Verma et al., 2011).

\section{Hepatoprotective and Immuno-modulatory activity}

Ethyl acetate fraction of flower extract exhibited hepatoprotective potential against carbon tetrachloride $\left(\mathrm{CCl}_{4}\right)$ induced liver damage in preventive and curative models. In addition, ethyl acetate fraction also significantly prevented the elevation of hepatic malondialdehyde formation and depletion of reduced glutathione content in the liver of $\mathrm{CCl}_{4}$ intoxicated rats in a dose dependent manner (Painuli et al., 2015). In another study, the ethanolic leaf extract significantly reduced the serum enzyme Alkaline phosphatase (ALP), serum glutamic oxaloacetic transaminase (SGOT), Serum Glutamic Pyruvic Transaminase (SGPT), triglyceride, total bilirubin, cholesterol and excretion of ascorbic acid in urine to the normal level in carbon tetrachloride treated rats (Acharya et al., 2011).Alcoholic extract of the leaves of $R$. arboreum was an effective and safe immunosuppressive agent (Bhandary and Kuwabata et al., 2008).

\section{Toxicity and anti-microbial activity}

The leaves exhibited significant cytotoxicity, while stem, roots had moderate effect with bark showing least significance. The presence of glycosides, alkaloids and flavonoids in the extract might be responsible for activity (Ali et al., 2008). The methanolic crude extracts of flower, leaf, stem and roots of $R$. arboreum possessed significant potency against $B$. subtilus, Salmonella typhi and S. aureus (Ali et al., 2008; Prakash et al., 2008). Prakash et al., (2008) stated that the leaf extract was fairly effective, than flower extract. The zone of inhibition of methanol and aqueous leaves extracts for $S$. aureus, Klebsiella pneumoniae, Streptococcus pyogene and E. coli (Chauhan et al., 2016). In 2013, Sharma and coworkers reported that ethanolic flower extract was very effective against $B$. subtilis, S.aureus, Salmonella typhi and Escherichia coli. Ethanol, methanol extract and isolated quercetin showed lowest effective concentration against $E$. coli and S. Aureus (Bhandary and Kuwabata et al., 2008). In another study, the ethanolic flower extract showed significant role against $E$. coli., S. epidermidis and $S$. aureus respectively and also showed antifungal activity against Aspergillus flavus, Candida albicans and Aspergillus parasiticus while the water extract, showed significant result against Candida albicans, Aspergillus parasiticus and for Aspergillus flavus (Saranya and Ravi 2016). Methanol and the ethyl acetate extract showed effective antifungal activity against Fusarium solani, Aspergillus niger, Microsporum canis, Cantharellus flavus, Candida albacan and Candida glaberata. The high activity of betulin and $3 \beta$-acetoxyurs-11, 12- epoxy-13 $\beta$ might be due to its hydrophilic nature (Ali et al., 2008). Chauhan et al., (2016) reported that methanol and aqueous leaf extract wereeffective against the fungus Trichoderma viride and Candida.

\section{CONCLUSION}

Present review focussed on the value of the Rhododendron in food and pharmaceutical industry. Rhododendron has a special value in the cultural and economic life of human beings. It is sometimes planted in religious places for decoration purposes. This plant has anti-inflammatory, hepato-protective, anti-diarrhoeal, anti-diabetic, antioxidant properties due to presence of secondary metabolites like flavonoids, saponins, tannins and other phytochemicals. However, young leaves when consumed in large quantities may cause intoxication. The commercial utilization of Rhododendron flower for various products may make it available throughout the year in the coming years. It can provide various opportunities in developing marketing strategies and employment to many people in rural areas. Although more research is needed for creating its awareness and benefits among consumers, further exploration are needed by food scientists for their existence in food market and to enhance the economy of the food producers.

\section{REFERENCES}

Acharya, K., Giri, S., Biswas, G. (2011). Comparative study of antioxidant activity and nitric oxide synthase activation property of different extracts from Rhododendron arboreum flower. International Journal of PharmTech Research. 3(2): 757-762.

Ali, M.S., Qaisar, M., Gilani, S.N., Shah, M.R., Khan, I., Ali, G. (2013). Antifungal activity of bioactive constituents and bark extracts of Rhododendron arboreum. Bangladesh J. Pharmacol. 8: 218-22.

Bhandari, L., Rajbhandari, M. (2014). Isolation of quercetin from flower petals, estimation of total phenolic, total flavonoid and antioxidant activity of the different parts of Rhododendron arboreum Smith. Scientific World. 12(12): 34-40.

Bhandary, M.R., Kuwabata, J. (2008). Antidiabetic activity of Laligurans (Rhododendron arboreum Smith) flower. J. of Food Sci. and Tech Nepal. 4: 61-63.

Bhattacharyya, D. (2011). Rhododendron species and their uses with special reference to Himalayas-A review. Assam University Journal of Science and Technology. 7(1): 161-167.

Chauhan, N.S. (1999). Medicinal and aromatic plants of Himachal Pradesh. Indus Publishing Company, New Delhi, 353.

Chauhan, P., Singh, J., Sharma, R.K. Easwari, T.S. (1999) Antibacterial activity of Rhododendron arboreum plant against Staphylococcus aureus. Annals of Horticulture. 9(1): 92-96.

Chauhan, P., Singh, J., Sharma, R.K.Easwari, T.S. (2016) Antibacterial activity of Rhododendron arboreum plant against Staphylococcus aureus. Annals of Horticulture. 9(1): 92-96.

Chettri, N., Sharma, E.A. (2009). Scientific assessment of traditional knowledge on firewood and fodder values in Sikkim, India. Forest Ecology and Management. 257(10): 2073-2078.

Dangwal, L.R., Singh, T., Singh, A. (2014). Exploration of wild edible plants used by Gujjar and Bakerwal tribes of District Rajouri ( $\mathrm{J}$ and $\mathrm{K}$ ). Indian Journal of Applied and Natural Science. 6(1): 164-169. 
Devi, S., Vats, C.K., Dhaliwal, Y.S. (2018). Quality evaluation of Rhododendron arboreum flowers of different regions of Himachal Pradesh for standardization of juice extraction technique. International Journal of Advances in Agricultural Science and Technology. 5(1): 51-57.

Gautam, V., Kohli, S., Arora, S., Bhardwaj, R., Kazi, M., Ahmad, A., Ahmad, P. (2018). Antioxidant and antimutagenic activities of different fractions from the leaves of Rhododendron arboreum Sm. and their GC-MS profiling. Molecules. 3: 23(9):2239. doi: 10.3390/molecules2309 2239.

Haq, F. (2012). The ethno botanical uses of medicinal plants of Allai Valley, Western Himalaya Pakistan. International Journal of Plant Research. 2(1): 21-34.

Hariharan, Rangaswami, S. (1966). Chemical investigation of the bark of Rhododendron arboretum. Sm- V. Curr. Sci Arc. 35: 390-391.

Jegan, B.S., Selvaraj, D. (2016). Bioactive components of the leaves of Rhododendron arboreum Sm. Ssp. Nilagiricum. World Journal of Pharmacy and Pharmaceutical Sciences. 5(7): 713-722.

Joshi, S.K., Ballabh, B., Negi, P.S., Dwivedi, S.K. (2018). Diversity, distribution, use pattern and evaluation of wild edible plants of Uttarakhand, India. Defence Life Science Journal. 3(2): 126-135.

Khare, C.P. (1980). Indian medicinal plants: an illustrated Dictionaeria Medica. Sree Bharati Press, Calcutt, 540.

Krishna, H., Attri, B.L., Kumar, A. (2014). Improvised Rhododendron squash: Processing effects on antioxidant composition and organoleptic attributes. Journal of Food Science and Technology. 51(11): 3404-3410.

Kumari, K., Srivastva, H., Mudgal, V.D. (2015). Medicinal importance and utilization of Rhododendron- A Review. Research in Environment and Life Sciences. 8(4): 761-766.

Mao, A., Singh, A., Hajra, P.K. (2001). In: Floristic Diversity and Conservation Strategies in India (Eds. Singh, N.P. and Singh, D.K.), BSI, Kolkata. IV: 2167-2202.

Middelkoop, T.B., Labadie, R.P. (1983). Evaluation of Asoka Aristha an indigenous medicine in Sri Lanka. Journal of Ethnopharmacology. 8(3): 313-320.

Murty, D., Rajesh, E., Raghava, D., Raghavan, T.V., Surulivel, M.K.M. (2010). Hypolipidemic effect of arborium plus in experimentally induced hypercholestermic rabbits. Yakugaku Zasshi.130(6): 841- 846.

Nand, K., Naithani, S. (2018). Ethnobotanical uses of wild medicinal plants by the local community in the Asi Ganga Subbasin, Western Himalaya. Journal of Complementary Medicine Research. 9(1): 34-46.

Negi, V.S., Maikhuri, R.K., Rawat, L.S., Chandra, A. (2013). Bioprospecting of Rhododendron arboreum for livelihood enhancement in central Himalaya, India. Environment and We. International Jouranl of Science and Technology. 8: $61-70$.

Nisar, M, Ali, S., Qaisar, M. (2013). Antibacterial and cytotoxic activities of the methanolic extracts of Rhododendron arboreum. Journal of Medicinal Plants Research 7(8): 398-403.

Nisar, M., Ali, S., Qaisar, M., Gilani, S.N., Shah, M.R., Khan, I., Ali, G. (2013). Antifungal activity of bioactive constituents and bark extracts of Rhododendron arboreum. Bangladesh J. Pharmacol. 8: 218-22.
Orwa, C., Mutua, A., Kindt, R., Jamnadass, R., Simons, A. (2009). Agroforest tree Database: a tree reference and selection guide version 4.0 available at (http://www.worldagro forestry.org/af/treedb/).

Painuli, S., Rai, N., Kumar, N. (2015). Gas chromatography and mass spectrometry analysis of methanolic extract of leaves of Rhododendron arboreum. Asian Journal of Pharmapsutical and Clinical Research. 9(1): 101-104.

Parcha, V., Yadav, N., Sati, A., Dobhal, Y., Sethi, N. (2017). Cardioprotective effect of various extract of Rhododendron arboretum Sm flower on Albino rats. Journal of Pharmacognosy and Phytochemistry. 6(4): 1703-1707.

Paul, A., Khan, M.L. Das, A.K. (2010). Utilization of rhododendrons by Monpas in western Arunachal Pradesh, India. Journal American Rhododendron Society. 64(2): 81-84.

Paul, A., Khan, M.L., Arunachalam, A., Arunachalam, K. (2005). Biodiversity and conservation of Rhododendrons in Arunachal Pradesh in the Indo-Burma biodiversity hotspot. Current Science. 89(4): 623.

Paxton, J. (1834). Paxton's magazine of botany and register of flowering plants. Vol 1.Orr and Smith, London, 101.

Prakash, D., Upadhyay, G., Singh, B.N., Dhakarey, R., Kumar, S., Singh, K.K. (2007). Free-radical scavenging activities of Himalayan Rhododendrons. Current Science. 92(4): 526-532.

Prakash, T., Fadadu, S.D., Sharma, U.R., Surendra, V., Goli, D., Stamina, P., Kotresha, D. (2008). Hepatoprotective activity of leaves of Rhododendron arboreum in $\mathrm{CCl} 4$ induced hepatotoxicity in rats. Journal of Medicinal Plants Research. 2(11): 315-320.

Rahman, I.U., Afzal, A., Iqbal, Z., ljaz, F., Ali, N., Bussmann, R.W. (2018). Traditional and Ethnomedicinal dermatology practices in Pakistan. Clinics in Dermatology. 36(3): 310-319.

Rai, T. and Rai, L. (1994). Tress of the Sikkim Himalaya. Indus Publishing Company, New Delhi, 94.

Rana, S.K., Oli, P.S., Rana, H.K. (2015). Traditional botanical knowledge (TBK) on the use of medicinal plants in Sikles area, Nepal. Asian Journal of Plant Science and Research. 5(11): 8-15.

Ranjitkar, S., Sujakhu, N.M., Jati, R., Xu, J., Schmidt-Vogt, D. (2014). Yield and household consumption of Rhododendron arboreum as a fuel wood species in Eastern Nepal. Biomass and Bioenergy. 61: 245-253.

Roy, J.D., Handique, A.K., Barua, C.C., Talukdar, A., Ahmed, F.A., Barua, I.C. (2014). Evaluation of phytoconstituents and assessment of adaptogenic activity in vivo in various extracts of Rhododendron arboreum (leaves). Indian Journal of Pharmaceutical and Biological Research. 2(2): 49-56.

Saklani, S. and Chandra, S. (2015). Evaluation of in vitro antimicrobial activity, nutritional profile and phytochemical screening of Rhododendron arboreum. World J. Pharm Sci. 4: 96271.

Saranya, D. and Ravi, R. (2016). The leaf of Nilgiri Rhododendron: a potent antimicrobial agent against medically critical human pathogens. International Journal of Pharmacognosy. 3(6): 251-256.

Sastry, A.R.K. and Hajra, P.K. (2010). Rhododendrons in India: floral and foliar splendour of the Himalayan flora. B.S. Publications, Hyderabad, 182 pp. 
Semwal, D.P., Saradhi, P.P., Kala, C.P., Sajwan, B.S. (2010). Medicinal plants used by local Vaidyas in Ukhimath block, Uttarakhand. Indian Journal of Traditional Knowledge. 9(3): 480-485.

Shanmugam, S., Annadurai, M., Rajendran, K. (2011). Ethnomedicinal plants used to cure diarrhoea and dysentery in Pachalur hills of Dindigul district in Tamil Nadu, Southern India. Journal of Applied Pharmaceutical Science. 1(8): 94-97.

Sharma, N., Sharma, U.K., Gupta, A.P., Sinha, A.K. (2010). Simultaneous determination of epicatechin, syringic acid, quercetin-3O- galactoside and quercitrin in the leaves of Rhododendron species by using a validated HPTLC method. Journal of Food Composition and Analysis. 23(3): 214-219.

Sharma, P. and Samant, S.S. (2014). Diversity, distribution and indigenous uses of medicinal plants in Parbati Valley of Kullu district in Himachal Pradesh, Northwestern Himalaya. Asian Journal of Advanced Basic Sciences. 2(1): 77-98.

Sharma, P., Agnihotry, A., Sharma, P.P., Sharma, L. (2013). Wild edibles of Murari Devi and surrounding areas in Mandi district of Himachal Pradesh, India. International journal of Biodiversity and Conservation. 5(9): 592-604.

Sharma, P.K., Chauhan, N.S., Lal, B. (2010). Conservation of Phytodiversity of Parvati Valley in Northwestern Himalayas of Himachal Pradesh-India. Medicinal and Aromatic Plant Science and Biotechnology. 4(1): 47-63.

Shilajan, S. and Swar, G. (2013). Simultaneous estimation of three triterpenoids-ursolic acid, beta-sitosterol and lupeol from flowers, leaves and formulations of Rhododendron arboreum Smith. using validated HPTLC method. International Journal of Green Pharmacy. 7(3): 206-210.

Soetan, K.O., Olaiya, C.O., Oyewole, O.E. (2010). The importance of mineral elements for humans, domestic animals and plants- A review. Afr. J. Food Sci. 4: 200-22.
Som, K., Madhvi, M. Sharma, lqbal, J., Mohd, Y. (2019). Phytochemistry, Traditional uses and Pharmacology of Rhododendron arboreum: A Review. Research J. Pharm. and Tech. 12(9): 4565-4574.

Sonar, P.K., Singh, R., Bansal, P., Balapure, A.K. Saraf, S.K. (2012). $R$. arboreum flower and leaf extracts: RP-HPTLC screening, isolation, characterization and biological activity. Rasayan Journal of Chemistry. 5(2): 165-172.

Srivastava, P. (2012). Rhododendron arboreum: An overview. J. Appl. Pharm. Sci. 2: 158-62.

Swaroop, A., Gupta, A.P., Sinha, A.K. (2005). Simultaneous determination of quercetin, rutin and coumaric acid in flowers of Rhododendron arboreumby HPTLC. Chromatographia. 62: 649-652.

Tiwari, O.N. and Chauhan, U.K. (2006). Rhododendron conservation in Sikkim Himalaya. Current Science. 90(4): 532-541.

Uniyal, S.K., Singh, K.N., Jamwal, P., Lal, B. (2006). Traditional use of medicinal plants among the tribal communities of Chhota Bhangal, Western Himalaya. Journal of Ethnobiology and Ethnomedicine. 2(1): 14.

Verma, N., Singh, A.P., Amresh, G., Sahu, P.K., Rao, C.V. (2010). Protective effect of ethyl acetate fraction of Rhododendron arboreum flowers against carbon tetrachloride-induced hepatotoxicity in experimental models. Indian Journal of Pharmacology, 43(3): 291-295.

Verma, N., Singh, A.P., Amresh, G., Sahu, P.K., Rao, C.V. (2011). Anti-inflammatory and anti-nociceptive activity of Rhododendron arboreum. J. Pharma Res. 3(6): 1376-1380.

Zhasa, N.N., Hazarika, P., Tripathi, Y.C. (2015). Indigenous knowledge on utilization of plant biodiversity for treatment and cure of diseases of human beings in Nagaland, India, A case study. International Research Journal of Biological Sciences. 4(4): 89-106. 